\title{
Androgen receptor CAG polymorphism and the risk of benign prostatic hyperplasia in a Brazilian population
}

\author{
Vanderlei Biolchi, Brasil Silva Neto, Walter Koff, IIma Simoni Brum
}

Department of Physiology, Instituto de Ciências Básicas da Saúde Universidade Federal do Rio Grande do Sul (VB, ISB) and Division of Urology, Hospital de Clinicas de Porto Alegre and Faculdade de Medicina, Universidade Federal do Rio Grande do Sul (BSN, WK), RS, Brazil

\section{ABSTRACT}

Benign prostatic hyperplasia (BPH) is a very frequent age-related proliferative abnormality in men. Polymorphic CAG repeat in the androgen receptor (AR) can alter transactivation of androgen-responsive genes and potentially influence BPH risk. We investigated the association between CAG repeat length and risk of BPH in a case-control study of a Brazilian population. We evaluated 214 patients; 126 with BPH and 88 healthy controls. DNA was extracted from peripheral leucocytes and the AR gene was analyzed using fragment analysis. Hazard ratio (HR) and 95\% confidence interval were estimated using logistic regression models. Mean CAG length was not different between patients with BPH and controls. The CAG repeat length was examined as a categorical variable (CAG $\leq 21$ vs. CAG $>21$ and CAG $\leq 22$ vs. CAG > 22) and did not differ between the control vs. the BPH group. We found no evidence for an association between AR CAG repeat length in BPH risk in a population-based sample of Brazilians.

\section{ARTICLE INFO}

\section{Key words:}

Receptors, Adrenergic;

Polymorphism, Genetic;

Benign Prostatic Hyperplasia

Int Braz J Urol. 2012; 38: 373-9

Submitted for publication: October 27, 2011

Accepted after revision: January 09, 2012

\section{INTRODUCTION}

Benign prostatic hyperplasia (BPH) is a very frequent age-related proliferative abnormality in men (1). BPH is considered a progressive disease, defined as continuous growth of the prostate, leading to intensification of symptoms and increased risk of complications, such as increased risk of acute urinary retention and BPH-related surgery (2). Studies show that the prevalence of $\mathrm{BPH}$ is around 40 to $50 \%$ at the age of 50 years, and approximately $80 \%$ at the age of $70(1,3)$.

The pathogenesis of tumor development has been closely associated with the action of steroid hormones $(4,5)$. The androgenic effects are mediated by testosterone and dihydrotestos- terone (DHT) in the target cells and their action has been demonstrated in the morphogenesis, differentiation, cell proliferation, and secretions of the prostate gland. Androgen binding promotes the activation of the androgen receptor (AR) and recruitment of co-factors, leading to the transcription of hormone-dependent target genes (6-9).

The human AR gene is located in chromosome $X$, on the q11-q12 region, which contains 8 exons (10) and has an approximate size of $90 \mathrm{~kb}$ (11). A critical function of the AR gene product is to activate the expression of other genes. The transactivation activity lies in the $\mathrm{N}-$ terminal domain of the protein (encoded by exon 1). Two polymorphic microsatellites are located approximately $1.1 \mathrm{~kb}$ away in exon 1: a highly 
polymorphic CAG repeat and a less polymorphic GGC repeat $(11,12)$. The CAG repeat encodes a polyglutamine tract; it ranges from 8 to 31 repeats and averages approximately 20 repeats (13).

In vitro studies have shown a negative correlation between the number of CAG repeats and the transcriptional activity of the AR. The increased number of these repeats reduces transcriptional activity in the AR, whereas a reduction to zero induces increased AR $(11,14,15)$.

Therefore, the objective of the present study was to investigate whether CAG variant can be related to the development of BPH analyzing the frequency of AR CAG polymorphism in a sample of male individuals from southern Brazil.

\section{MATERIALS AND METHODS}

\section{Study population}

This case-control study was prospectively conducted at the Universidade Federal do Rio Grande do Sul from September 2004 to January 2009. The study was approved by the local and national Ethics Committee and informed consent was obtained from every subject. Prostate hyperplasia patients were selected from the Urology outpatient clinic at the Hospital de Clínicas de Porto Alegre. Inclusion criteria were age 4080 years old, prostate volume larger than $30 \mathrm{~g}$ (evaluated by abdominal ultrasound to define BPH group), no past or current hormone-ablation therapy or $5 \alpha$-reductase inhibitor therapy, and no concomitant neoplasia. Patients were submitted to surgery and the diagnosis of BPH was confirmed by pathological examination. Factors such as age at diagnosis, race (self-described), tumor stage and grade, total serum PSA (prostatespecific antigen) at diagnosis, and family history were recorded. Blood was collected to perform polymorphism analysis and to measure total serum testosterone. Controls were selected from a prostate cancer prevention program conducted since 2004 at the same institution. Inclusion criteria were age 40-80 years, prostate volume smaller than $30 \mathrm{~g}$, PSA value less than $2.0 \mathrm{ng} /$ $\mathrm{mL}$, normal digital rectal examination, and no concomitant neoplasia.

\section{Genotyping}

Genomic DNA for patients and controls was extracted from peripheral blood leukocytes. After erythrocyte lysis, leukocyte lysis was performed using $2 \mathrm{~mL}$ of specific solution $(\mathrm{NaCl}$ 150 mM, Tris- $\mathrm{HCl} 10 \mathrm{mM}$, pH 8.0; EDTA $10 \mathrm{mM}$, $\mathrm{pH} 8.0$ ), $36 \mu \mathrm{L} 10 \% \mathrm{SDS}$, and $30 \mu \mathrm{L}$ of proteinase $\mathrm{K}(10 \mathrm{mg} / \mathrm{mL})$, incubated at $37^{\circ} \mathrm{C}$ for 18 hours. DNA was extracted and precipitated with 70\% ethanol and re-suspended with specific buffer TE 10:0.1 (Tris- $\mathrm{HCl} 10 \mathrm{mM}$, pH 8.0; EDTA 0.1 $\mathrm{mM}, \mathrm{pH}$ 8.0).

PCR was carried out at a final volume of $50 \mu \mathrm{L}$. One $\mu \mathrm{L}$ of the genomic DNA was denatured at $96{ }^{\circ} \mathrm{C}$ for $2 \mathrm{~min}$ in the presence of 20 $\mathrm{mM}$ Tris- $\mathrm{HCl} \mathrm{pH} 8.4$ plus $50 \mathrm{mM} \mathrm{KCl}$ and $1.5 \mathrm{mM}$ $\mathrm{MgCl} 2$. After this hot start, $1.25 \mathrm{U}$ of Taq DNA polymerase was added together with the same Tris- $\mathrm{HCl}$ buffer, $1.5 \mathrm{mM} \mathrm{MgCl}, 0.4 \mu \mathrm{M}$ sense and antisense primers and $0.2 \mathrm{mM}$ dNTP mix.

The primers used for polymorphism amplification were CAG primer 5'-TCCAGAATCTGTTCCAGAGCGTGC-3' (forward) and 5'-GCTGTGAAGGTTGCTGTTCCTCAT-3' (reverse). Both sense primers were labeled with FAM fluorescent dye. Amplifications were performed using an automated thermal cycler (MJ Research, Waltham, MA, USA) applying the following conditions: hot start, 2 min at $96{ }^{\circ} \mathrm{C}$; three cycles of $40 \mathrm{sec}$ at $94{ }^{\circ} \mathrm{C}, 30 \mathrm{sec}$ at $67{ }^{\circ} \mathrm{C}$ and $20 \mathrm{sec}$ at $72{ }^{\circ} \mathrm{C}$; three cycles under the same physical conditions except for the annealing temperature, which was $64{ }^{\circ} \mathrm{C}$; three cycles at an annealing temperature of $61{ }^{\circ} \mathrm{C}$; three cycles at an annealing temperature of $59{ }^{\circ} \mathrm{C}$; and 25 cycles at an annealing temperature of $55{ }^{\circ} \mathrm{C}$. The quality of the PCR products was assessed using 1.5\% agarose gel electrophoresis. Each PCR product was diluted in water (10X) for analysis, and 2 $\mu \mathrm{L}$ were mixed with deionized formamide and a fluorescent molecular weight marker [GeneMapper 500HD (ROX) Size Standard, Applied Biosystems, Foster City, CA, USA]. After denaturation for $1 \mathrm{~min}$ at $95{ }^{\circ} \mathrm{C}$, each sample was submitted to capillary electrophoresis on an ABI 3100-Avant automated sequencer and the PCR products were analyzed with the GeneMapper software (Applied Biosystems, Foster City, CA, USA). The 
number of CAG was calculated based on the size of the PCR products considering a series of standards obtained by direct sequencing of PCR products.

\section{Statistical analysis}

Differences between means in the continuous variables were analyzed by $\mathrm{T}$ test, with $95 \%$ significance. The genotype frequency between cases and controls was tested using standard $\chi^{2}$ tests. Logistic regression was used to provide hazard ratio (HR), 95\% confidence intervals (CI) and p-values for the risk of CAG repeat with BPH. The CAG repeat lengths were examined as categorical variables $(\mathrm{CAG} \leq 21$ vs. $\mathrm{CAG}>21$ and $\mathrm{CAG} \leq 22$ vs. $\mathrm{CAG}>$ 22). The categories were defined based on median analysis. Data analysis was performed using the computer software SPSS for windows (version 16.0).

\section{RESULTS}

The characteristics of the studied population are shown in Table-1. Genomic DNA from 126 BPH patients and 88 healthy male controls was ex- amined to determine the number of CAG repeats. The participant's mean age was $62.84 \pm 9.15$ in the $\mathrm{BPH}$ group and $56.68 \pm 8.08$ in the control group. BPH patients were older than controls $(\mathrm{p}<0.001)$. There was a predominance of white individuals in both groups (89.7 BPH and 82.3\% controls). Total serum PSA was $0.76(0.55-1.05) \mathrm{ng} / \mathrm{mL}$ in the control group and $1.47(0.69-3.94) \mathrm{ng} / \mathrm{mL}$ in the $\mathrm{BPH}$ group. PSA was not different between the groups $(\mathrm{p}=0.566)$. The prostatic volume was 20.00 (14.3823.94) $\mathrm{cm}^{3}$ in the control group and 35.68 (30.0049.00) $\mathrm{cm}^{3}$ in the BPH group. Prostatic volume was higher in the BPH group than in the control group $(p<0.001)$. The mean number of CAG repeats in exon 1 of the AR was $22.11 \pm 2.89$ in the control group and $21.62 \pm 2.84$ in the BPH group (Table-1). No significant difference was found between the mean CAG repeats of cases and controls. The distribution frequency of the number of CAG repeat polymorphisms is shown in Figure-1.

Based on the median number of CAG repeats in the control group, the population studied was dichotomously classified into different subgroups, $\mathrm{CAG} \leq 21$ vs. $\mathrm{CAG}>21$ and $\mathrm{CAG} \leq 22$ vs. $\mathrm{CAG}>$

Table 1 - Characteristics of study population $(n=344)$.

\begin{tabular}{|c|c|c|}
\hline & $\mathrm{BPH}(\mathrm{n}=126)$ & Controls $(\mathrm{n}=88)$ \\
\hline \multicolumn{3}{|l|}{ Age (years) $^{c}$} \\
\hline Mean \pm SD & $62.84 \pm 9.15$ & $56.68 \pm 8.08$ \\
\hline Range & $41-82$ & $41-75$ \\
\hline Race (caucasians) ${ }^{\mathrm{a}}$ & $113(89.7 \%)$ & 73 (82.3\%) \\
\hline PSA $(n g / m L)^{b, c}$ & $1.47(0.69-3.94)$ & $0.76(0.55-1.05)$ \\
\hline Volume $\left(\mathrm{cm}^{3}\right)^{\mathrm{b}, \mathrm{c}}$ & $35.68(30.00-49.00)$ & $20.00(14.38-23.94)$ \\
\hline \multicolumn{3}{|l|}{ CAG repeat } \\
\hline Mean \pm SD & $21.62 \pm 2.84$ & $22.11 \pm 2.89$ \\
\hline Median & 21 & 21.5 \\
\hline Range & $13-31$ & $16-30$ \\
\hline
\end{tabular}

Values are expressed as anumber of cases and (\%), ${ }^{b}$ median and percentile $25 / 75, \stackrel{c}{ } \mathrm{P}<0.05$. 
Figure 1 - Frequency distribution of CAG repeats in the control and BPH groups.

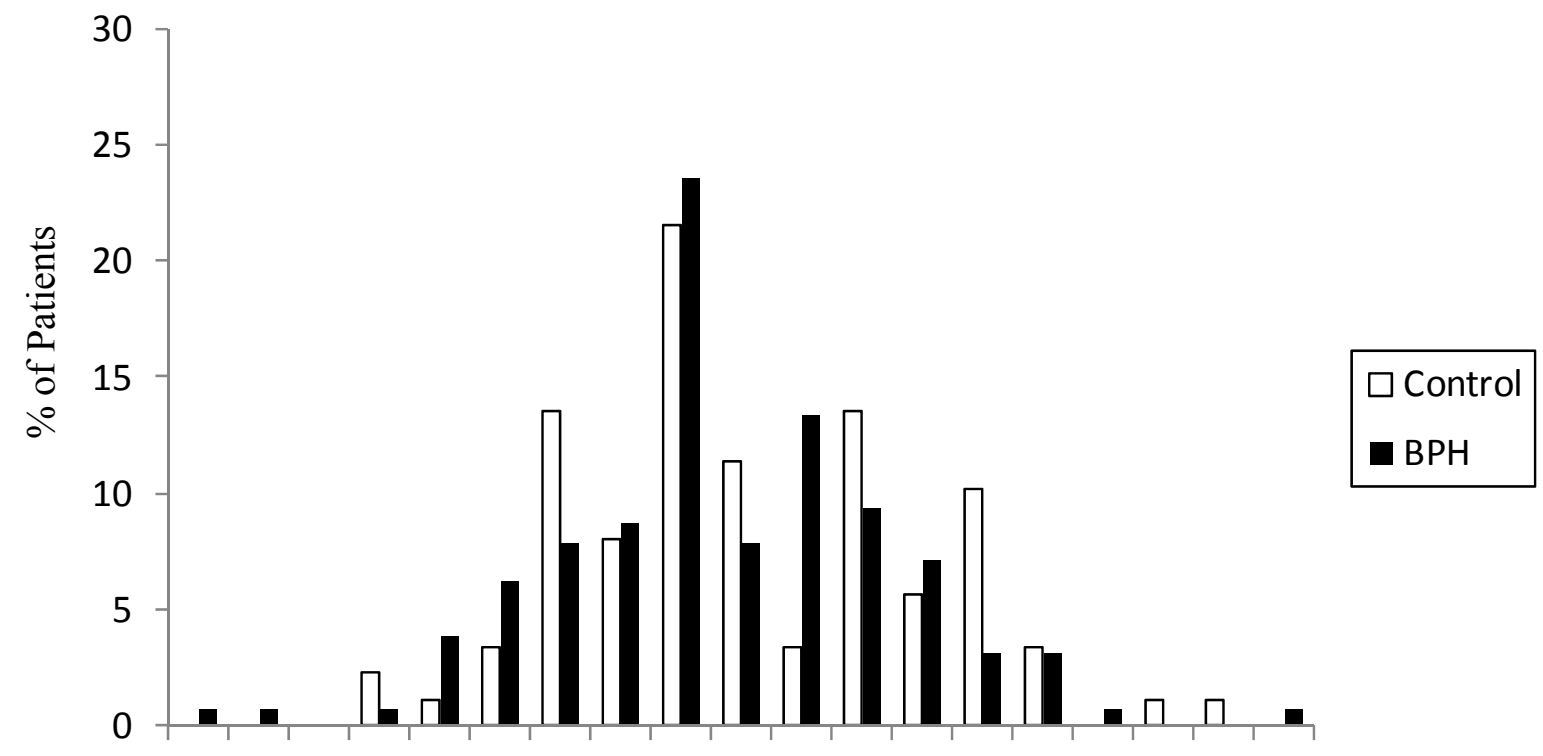

$\begin{array}{lllllllllllllllllll}13 & 14 & 15 & 16 & 17 & 18 & 19 & 20 & 21 & 22 & 23 & 24 & 25 & 26 & 27 & 28 & 29 & 30 & 31\end{array}$

CAG Repeat Lenght

22 (Table-2). According to this analysis, 66.3\% of BPH group presented CAG > 21 and 56.9\% presented CAG $\leq 21(\mathrm{p}=0.352)$ and $58 \%$ of BPH group presented CAG $>22$ and $58.8 \%$ presented CAG $\leq 22(\mathrm{p}=0.513)$. The distribution frequency between the both groups was similar. There was no difference regarding any other dichotomic classification of the groups (data not show).

Considering that age is one of the major risk factors for prostate cancer and BPH development, we evaluated the risk of the genotypes de- scribed above to develop these pathologies using logistic regression analysis, considering age as a continuous variable in the regression model (Table-3). The risk of developing BPH in individuals who have CAG $>21$ compared to $\mathrm{CAG} \leq 21$ was 1.013 (95\%CI 0.752-1.365; $p=0.932$ ), whereas the comparison between individuals with CAG > 22 and $C A G \leq 22$ showed a risk of $0.891(95 \% \mathrm{CI}$ 0.488-1.627; $\mathrm{p}=0.708$ ). Similarly, we found no difference regarding any other dichotomic classification of the groups (data not show).

Table 2 - Frequency distribution of CAG-21 and CAG-22 genotypes between BPH patients and controls.

\begin{tabular}{lcccc}
\hline & $n$ & BPH n (\%) & Controls n (\%) & $p^{*}$ \\
\hline $\mathrm{CAG} \leq 21$ & 102 & $58(56.9 \%)$ & $44(43.1 \%)$ & 0.352 \\
$\mathrm{CAG}>21$ & 101 & $67(66.3 \%)$ & $44(33.7 \%)$ & \\
$\mathrm{CAG} \leq 22$ & 131 & $77(58.8 \%)$ & $54(41.2 \%)$ & 0.513 \\
$\mathrm{CAG}>22$ & 81 & $47(58 \%)$ & $34(42 \%)$ & \\
\hline
\end{tabular}


Table 3 - Risk analysis for BPH of CAG-21 and CAG-22 genotypes

\begin{tabular}{lccc} 
& BPH HR & $95 \% \mathrm{Cl}$ & $\mathrm{p}^{*}$ \\
\hline $\mathrm{CAG} \leq 21$ & 1.013 & $0.752-1.365$ & 0.932 \\
$\mathrm{CAG}>21$ & & & \\
$\mathrm{CAG} \leq 22$ & 0.891 & $0.488-1.627$ & 0.708 \\
$\mathrm{CAG}>22$ & & & \\
\hline
\end{tabular}

\section{DISCUSSION}

Our results showed no association between AR CAG allele length and risk of developing BPH.

The AR is a transactivation factor that depends on the binding of a steroid hormone. This androgen-regulated transactivation activity is a key factor in the proliferation and differentiation of prostate cells. The polymorphic variation of the AR gene regulatory region, where the polymorphisms with the highest variation are located (CAG and GGC), may alter the transcriptional activity of the receptor (11).

In the present study, we found no significant difference in the number of CAG repeats between the control and BPH groups. The few studies that investigated AR CAG repeat and the risk to develop BPH have shown conflicting results. Our findings corroborate some data from the literature that also did not demonstrate differences between CAG repeat means in BPH patients and controls (16-18). AR CAG repeats were not associated with the risk to develop BPH, but shorter AR CAG repeats and PSA non-GG genotypes were significantly associated with decreased risk in BPH patients (19). However, in a recent case-control study of $416 \mathrm{BPH}$ cases and 527 controls, CAG repeat length was associated with the risk of incidence of BPH (20). In another recent study conducted in Iranian patients, the mean number of CAG repeat in BPH patients was significantly smaller than normal (19.9 vs. $21.9 ; p<0.0001)$ (21).

Studies suggest that the number of CAG and GGC repeats may be related to the ethnic group. In African-American populations, the mean number of repeats was demonstrated to be lower than among Caucasians $(13,22,23)$. The same was found in certain African subpopulations $(13,23,24)$, while the Asian population would have a larger mean number of repeats $(23,25)$. This might partly account for the frequency distribution of prostate cancer in the different regions of the world. In the present study, the proportion of black individuals was small and homogeneously distributed among the BPH and control groups. A separate analysis taking this factor into account did not show any differences. Moreover, in our study, information on race (or skin color) was collected by the examiner, a method that is not sufficiently adequate to define race/ethnicity. In fact, in Brazil as a whole, it is particularly difficult to assess race, due to the extensive genetic heterogeneity observed and the overlap of genetic characteristics among Europeans, Africans, and Native Americans (26). However, the patients' color distribution was the same as the one found by Parra et al., who analyzed skin color and genomic ancestry in Brazilians and found an European dominance in the south of Brazil (27). Germans and Italians are the main immigrant groups in Rio Grande do Sul, a southern Brazilian state (28). According to the last demographic census, $87.5 \%$ of the state population was classified as white, $5 \%$ as black, $7 \%$ as brown, $0.1 \%$ as Asian, and $0.4 \%$ as Amerindian; whereas in Brazil, 53.7\% are white, 6.2\% are black, 38.4\% are brown, $0.4 \%$ are Asian, and 0.4\% are Amerindians (IBGE Census 2000; http:// ibge.gov.br).

It is believed that AR activity is inversely correlated with CAG repeat length based on investigations conducted using reporter-systems containing viral promoters $(11,13,14,29)$. Furthermore, recent new results about AR activity and CAG repeats have been demonstrated. Nenonen et al. demonstrated that the CAG repeat number is not inversely associated with AR activity in vitro when analyzing CAG lengths within normal range $(16,22$ and 28$)$ in a reporter-assay with the human PSA promoter as target. Using $\beta$-galactosidase as transfection control, 22CAG had the highest activity compared with 16CAG and 28CAG, whereas using renilla-luciferase the authors found that 16CAG behaved similarly to 22CAG and 28CAG, showing lower activity (30). 


\section{CONCLUSIONS}

Our results suggest that specific haplotype of AR is not essential to develop BPH. In conclusion, our data suggest no evidence for an association between AR CAG repeat length and BPH risk in a population-based sample of Brazilians.

\section{ABBREVIATIONS}

AR - Androgen Receptor

BPH - Benign Prostatic Hyperplasia

CI - Confidence Intervals

DHT - Dihydrotestosterone

DNA - Deoxyribonucleic Acid

HR - Hazard Ratio

kb - Kilo-base Pair

PCR - Polymerase Chain Reaction

PSA - Prostate-Specific Antigen

SPSS - Statistical Package for the Social Sciences

\section{ACKNOWLEDGMENTS}

Grant sponsor: FAPERGS/RS; grant number 0413137, FIPE/HCPA 04243

\section{CONFLICT OF INTEREST}

None declared.

\section{REFERENCES}

1. Kirby RS: The natural history of benign prostatic hyperplasia: what have we learned in the last decade? Urology. 2000; 56(5 Suppl 1): 3-6.

2. Carson C, 3rd, Rittmaster R: The role of dihydrotestosterone in benign prostatic hyperplasia. Urology. 2003; 61(4 Suppl 1): 2-7.

3. Platz EA, Smit E, Curhan GC, Nyberg LM, Giovannucci E: Prevalence of and racial/ethnic variation in lower urinary tract symptoms and noncancer prostate surgery in U.S. men. Urology. 2002; 59: 877-83.

4. Geck P, Szelei J, Jimenez J, Sonnenschein C, Soto AM: Early gene expression during androgen-induced inhibition of proliferation of prostate cancer cells: a new suppressor candidate on chromosome 13, in the BRCA2-Rb1 locus. J Steroid Biochem Mol Biol. 1999; 68: 41-50.
5. Latil A, Bieche I, Vidaud D, Lidereau R, Berthon P, Cussenot 0 , et al.: Evaluation of androgen, estrogen (ER alpha and ER beta), and progesterone receptor expression in human prostate cancer by real-time quantitative reverse transcription-polymerase chain reaction assays. Cancer Res. 2001; 61: 1919-26.

6. Avances C, Georget V, Terouanne B, Orio F, Cussenot 0 , Mottet N, et al.: Human prostatic cell line PNT1A, a useful tool for studying androgen receptor transcriptional activity and its differential subnuclear localization in the presence of androgens and antiandrogens. Mol Cell Endocrinol. 2001; 184: 13-24.

7. Gobinet J, Poujol N, Sultan C: Molecular action of androgens. Mol Cell Endocrinol. 2002; 198: 15-24.

8. Nakano K, Fukabori Y, Itoh N, Lu W, Kan M, McKeehan WL, et al.: Androgen-stimulated human prostate epithelial growth mediated by stromal-derived fibroblast growth factor-10. Endocr J. 1999; 46: 405-13.

9. Planz B, Wang Q, Kirley SD, Marberger M, McDougal WS: Regulation of keratinocyte growth factor receptor and androgen receptor in epithelial cells of the human prostate. $J$ Urol. 2001; 166: 678-83.

10. Lubahn DB, Joseph DR, Sullivan PM, Willard HF, French FS, Wilson EM: Cloning of human androgen receptor complementary DNA and localization to the $X$ chromosome. Science. 1988; 240: 327-30.

11. Chamberlain NL, Driver ED, Miesfeld RL: The length and location of CAG trinucleotide repeats in the androgen receptor $\mathrm{N}$-terminal domain affect transactivation function. Nucleic Acids Res. 1994; 22: 3181-6.

12. Sleddens HF, Oostra BA, Brinkmann A0, Trapman J: Trinucleotide (GGN) repeat polymorphism in the human androgen receptor (AR) gene. Hum Mol Genet. 1993; 2: 493.

13. Edwards A, Hammond HA, Jin L, Caskey CT, Chakraborty $\mathrm{R}$ : Genetic variation at five trimeric and tetrameric tandem repeat loci in four human population groups. Genomics. 1992; 12: 241-53.

14. Beilin J, Ball EM, Favaloro JM, Zajac JD: Effect of the androgen receptor CAG repeat polymorphism on transcriptional activity: specificity in prostate and non-prostate cell lines. J Mol Endocrinol. 2000; 25: 85-96.

15. Ding D, Xu L, Menon M, Reddy GP, Barrack ER: Effect of GGC (glycine) repeat length polymorphism in the human androgen receptor on androgen action. Prostate. 2005; 62: 133-9.

16. Bousema JT, Bussemakers MJ, van Houwelingen KP, Debruyne FM, Verbeek AL, de La Rosette JJ, et al.: Polymorphisms in the vitamin $D$ receptor gene and the androgen receptor gene and the risk of benign prostatic hyperplasia. Eur Urol. 2000; 37: 234-8.

17. Mononen N, Ikonen T, Autio V, Rokman A, Matikainen MP, Tammela TL, et al.: Androgen receptor CAG polymorphism and prostate cancer risk. Hum Genet. 2002; 111: 166-71. 
18. Schatzl G, Madersbacher S, Gsur A, Preyer M, Haidinger $G$, Haitel $A$, et al.: Association of polymorphisms within androgen receptor, 5alpha-reductase, and PSA genes with prostate volume, clinical parameters, and endocrine status in elderly men. Prostate. 2002; 52: 130-8.

19. Das K, Cheah PY, Lim PL, Zain YB, Stephanie FC, Zhao Y, et al.: Shorter CAG repeats in androgen receptor and non-GG genotypes in prostate-specific antigen loci are associated with decreased risk of benign prostatic hyperplasia and prostate cancer. Cancer Lett. 2008; 268: 340-7.

20. Kristal AR, Schenk JM, Song Y, Arnold KB, Neuhouser ML, Goodman PJ, et al.: Serum steroid and sex hormone-binding globulin concentrations and the risk of incident benign prostatic hyperplasia: results from the prostate cancer prevention trial. Am J Epidemiol. 2008; 168: 1416-24.

21. Ashtiani ZO, Hasheminasab SM, Ayati M, Goulian BS, Modarressi MH: Are GSTM1, GSTT1 and CAG Repeat Length of Androgen Receptor Gene Polymorphisms Associated with Risk of Prostate Cancer in Iranian Patients? Pathol Oncol Res. 2011; 17: 269-75.

22. Balic I, Graham ST, Troyer DA, Higgins BA, Pollock BH, Johnson-Pais TL, et al.: Androgen receptor length polymorphism associated with prostate cancer risk in Hispanic men. J Urol. 2002; 168: 2245-8.

23. Platz EA, Rimm EB, Willett WC, Kantoff PW, Giovannucci $\mathrm{E}$ : Racial variation in prostate cancer incidence and in hormonal system markers among male health professionals. J Natl Cancer Inst. 2000; 92: 2009-17.

24. Kittles RA, Young D, Weinrich S, Hudson J, Argyropoulos $G$, Ukoli $F$, et al.: Extent of linkage disequilibrium between the androgen receptor gene CAG and GGC repeats in human populations: implications for prostate cancer risk. Hum Genet. 2001; 109: 253-61.
25. Hsing AW, Gao YT, Wu G, Wang X, Deng J, Chen YL, et al.: Polymorphic CAG and GGN repeat lengths in the androgen receptor gene and prostate cancer risk: a population-based case-control study in China. Cancer Res. 2000; 60: 5111-6.

26. Silva Neto B, Koff WJ, Biolchi V, Brenner C, Biolo KD, Spritzer PM, et al.: Polymorphic CAG and GGC repeat lengths in the androgen receptor gene and prostate cancer risk: analysis of a Brazilian population. Cancer Invest. 2008; 26: 74-80.

27. Parra FC, Amado RC, Lambertucci JR, Rocha J, Antunes CM, Pena SD: Color and genomic ancestry in Brazilians. Proc Natl Acad Sci U S A. 2003; 100: 177-82.

28. Marrero AR, Das Neves Leite FP, De Almeida Carvalho B, Peres LM, Kommers TC, Da Cruz IM, et al.: Heterogeneity of the genome ancestry of individuals classified as White in the state of Rio Grande do Sul, Brazil. Am J Hum Biol. 2005; 17: 496-506.

29. Tut TG, Ghadessy FJ, Trifiro MA, Pinsky L, Yong EL: Long polyglutamine tracts in the androgen receptor are associated with reduced trans-activation, impaired sperm production, and male infertility. J Clin Endocrinol Metab. 1997; 82: 3777-82.

30. Nenonen H, Bjork C, Skjaerpe PA, Giwercman A, Rylander L, Svartberg J, et al.: CAG repeat number is not inversely associated with androgen receptor activity in vitro. Mol Hum Reprod. 2009; 16: 153-7.

\footnotetext{
Correspondence address:

Dr. Ilma Simoni Brum Department of Physiology,

Universidade Federal do Rio Grande do Sul Rua Sarmento Leite, 500 Porto Alegre, RS, 90050-170, Brazil Fax: +55 51-3308-3656 E-mail: ilma@ufrgs.br
} 